Provided for non-commercial research and education use. Not for reproduction, distribution or commercial use.

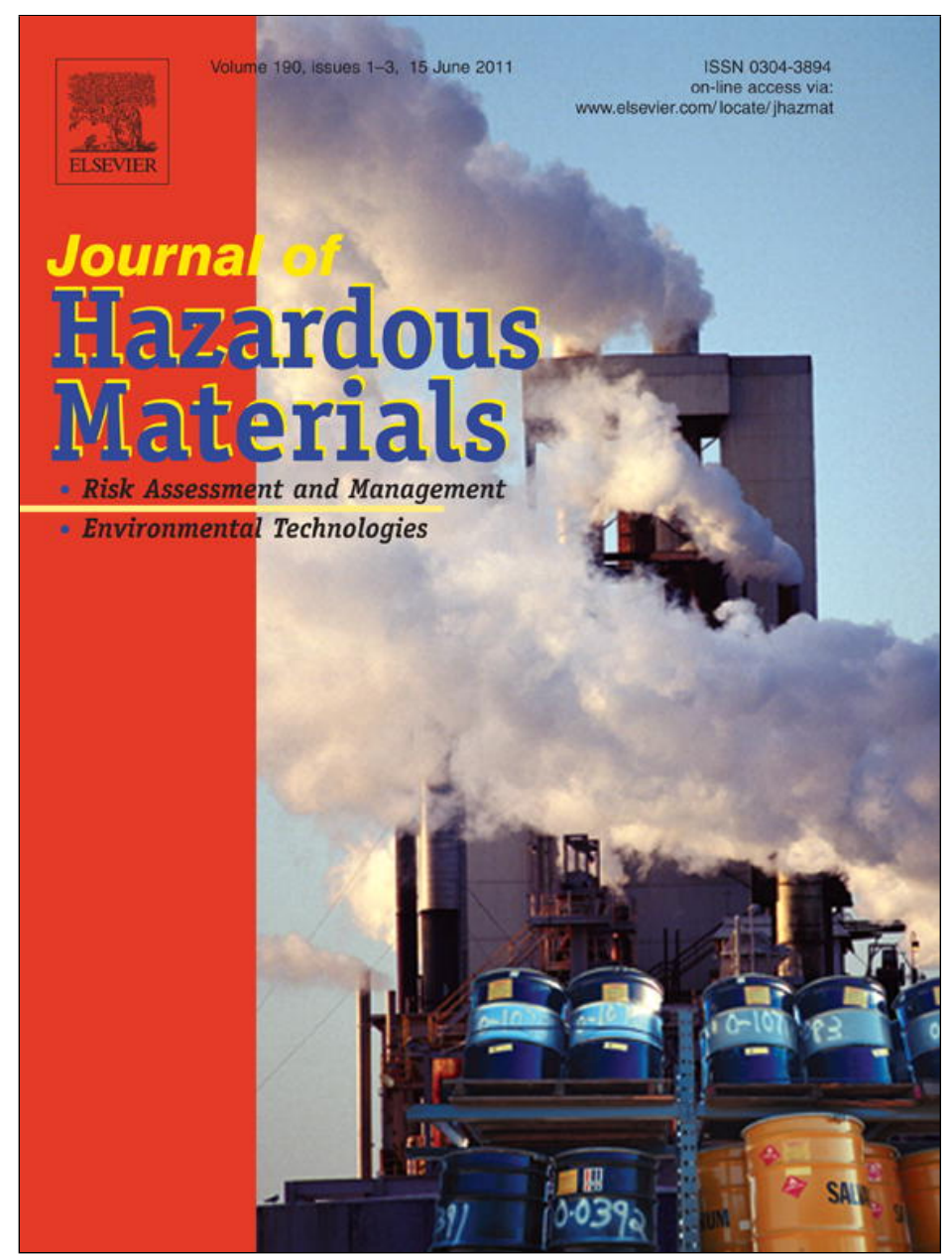

This article appeared in a journal published by Elsevier. The attached copy is furnished to the author for internal non-commercial research and education use, including for instruction at the authors institution and sharing with colleagues.

Other uses, including reproduction and distribution, or selling or licensing copies, or posting to personal, institutional or third party websites are prohibited.

In most cases authors are permitted to post their version of the article (e.g. in Word or Tex form) to their personal website or institutional repository. Authors requiring further information regarding Elsevier's archiving and manuscript policies are encouraged to visit:

http://www.elsevier.com/copyright 


\title{
Modified Ponorogo bentonite for the removal of ampicillin from wastewater
}

\author{
Andi Kurniawan Rahardjo, Maria Josephine Jeannette Susanto, Alfin Kurniawan, Nani Indraswati, \\ Suryadi Ismadji* \\ Department of Chemical Engineering, Widya Mandala Surabaya Catholic University, Kalijudan 37, Surabaya 60114, Indonesia
}

\section{A R T I C L E I N F O}

\section{Article history:}

Received 3 December 2010

Received in revised form 24 March 2011

Accepted 12 April 2011

Available online 19 April 2011

\section{Keywords:}

Ampicillin

Organo-bentonite

Adsorption

\begin{abstract}
A B S T R A C T
The adsorption of ampicillin onto natural and organo-bentonite was studied. Organo-bentonite was obtained by modifying the natural bentonite obtained from Ponorogo, Indonesia, using CTAB surfactant by microwave heating. The temperature dependent form of the Langmuir, Freundlich, Sips and Toth equations was employed to correlate equilibrium data. Based on the evaluation of the physical meaning of fitted isotherm parameters of each model, it is clear that Toth equation can represent the equilibrium data better than other models. The adsorption performance of natural and organo-bentonite for the removal of ampicillin from pharmaceutical company wastewater was also studied. In real wastewater, both adsorbents could not completely remove the ampicillin due to the sorption competition with other substances which also present in the wastewater.
\end{abstract}

(C) 2011 Elsevier B.V. All rights reserved.

\section{Introduction}

Antibiotics are designed specifically as a drug to treat or prevent infective diseases in human or animal body. The use of antibiotics has become an indispensable in human life and the global market consumption of these drugs increase steadily every year. For preventing or treating infections in humans or animals, only some parts of the antibiotics given dose are metabolized and the rest are excreted still as active compound [1,2]. Residues from human environments, medical wastes, farms, pharmaceutical and hospitals sewage may contain various antibiotics and antibiotic resistance genes that can contaminate natural environments [1]. In addition, antibiotics and antibiotic resistance genes can also accumulate through industrial route, where the concentration is usually much higher than that originated from public excretion [2]. The exposure of antibiotics in aquatic environment may increase the number of antibiotic resistant bacteria. These may pose a serious threat to public health in that more and more infections may no longer be treatable with known antibiotics [3].

Ampicillin is a beta-lactam that has been used extensively to treat infections caused by both gram-positive and gram-negative bacteria. Ampicillin is part of the amino penicillin family and is roughly equivalent to its successor, amoxicillin in terms of spectrum and level of activity. Ampicillin is against microorganisms

\footnotetext{
* Corresponding author. Tel.: +62 313891264; fax: +62 313891267.

E-mail addresses: suryadiismadji@yahoo.com, suryadi@mail.wima.ac.id (S. Ismadji).
}

by inhibiting the synthesis of cell wall during active multiplication. Currently, ampicillin is used to treat a wide range of diseases and infections such as gonorrhea, urinary tract infections, ear, nose and throat infections. Similar to its successor, ampicillin has also been known to be hardly degradable, still remains as active compound in urine and human feces [4]. The existence of ampicillin in environment causes some potential problems due to increasing of ampicillin resistant bacteria. Approximately 35-40\% of E. coli isolates are resistant to ampicillin, also more than $95 \%$ of all K. pneumonia isolates are similarly inherently resistant to this antibiotic [4].

The removal of ampicillin from pharmaceutical wastewater is quite expensive, however this wastewater must be treated properly prior to the release into environment. Among the available process for the treatment of wastewater containing antibiotics, the adsorption process is considered as the most effective and efficient method [2,5-8]. The main drawback of adsorption process for wastewater treatment is the cost of adsorbent. Commercially available adsorbents such as activated carbon are expensive. If inexpensive and abundantly available materials are found in nature as the alternative adsorbents, the adsorption process offers a very attractive method for environmental remediation.

Bentonite is a low cost material that widely used in many fields of material science technology and the utilization of this clay material for the treatment of wastewater containing hazardous substances has received great attention in recent years [9-11]. Indonesia has a huge bentonite reserve located in several provinces and it has potential application for industrial wastewater treatment. However, studies about the utilization of bentonite 
for the treatment of antibiotic effluent are still very scarce. To the best of our knowledge, the study of ampicillin removal by using bentonite and its modified form (organo-bentonite) originated from Indonesia is not available in the literature. In this study, we employed bentonite from Ponorogo as the raw material for organo-bentonite preparation. A cationic surfactant, cethyltrimethylammonium bromide (CTAB) was employed as the modifying agent.

The use of temperature dependent form of various isotherm models in representing liquid phase adsorption experimental data in the adsorption of antibiotic is still not available in the literature. All of adsorption studies of antibiotic only compared their experimental data with adsorption models at single temperature $[2,12,13]$. It is important that temperature dependent should be presented in correlating experimental data by different isotherm models at various temperatures. The temperature dependent form of the Langmuir, Freundlich, Sips and Toth equation was employed to represent experimental data in this study. The validity and physical meaning analysis of the isotherm parameters were also imparted in selecting the best model.

\section{Materials and methods}

\subsection{Materials preparation}

Ampicillin was obtained as trihydrate from PT. Coronet Crown, Sidoarjo, East Java, Indonesia and used without any further treatment. Bentonite was acquired from a mining site located on Ponorogo, East Java, Indonesia. Prior to the use, the bentonite was purified to remove any organic and inorganic impurities using $\mathrm{H}_{2} \mathrm{O}_{2}$. The suspension was heated at $100^{\circ} \mathrm{C}$ to remove excess hydrogen peroxide. Subsequently, the bentonite was rinsed with deionized water at least three times and dried in an oven (Memmert UM 400) for $2 \mathrm{~h}$ at $105^{\circ} \mathrm{C}$. The purified bentonite was crushed into powder by using microhammer mill (JANKE and KUNKEL) to obtain particle size of $-100 /+120$ mesh. The cation exchange capacity (CEC) of the bentonite was $57 \mathrm{meq} / 100 \mathrm{~g}$ clay based on the ASTM C837-99 procedure. The cetyltrimethylammonium bromide (CTAB), which belongs to quaternary ammonium salts, was used as modifying agent in organo-bentonite preparation.

\subsection{Preparation of organo-bentonite}

Organo-bentonite was synthesized according to following procedure: $2.0 \mathrm{~g}$ of natural bentonite was dispersed in $10 \mathrm{~mL}$ of distilled water containing $\mathrm{CTAB}$ with the amount of equivalent to 1.5 times of the CEC of the natural bentonite. The suspension was then stirred at $60^{\circ} \mathrm{C}$ for $15 \mathrm{~min}$ and dried in a microwave oven (National NN-S327 WF) at $600 \mathrm{~W}$ for $5 \mathrm{~min}$. The resulting organobentonite was repeatedly washed with deionized water to remove the superficially CTAB adsorbed on the adsorbent surface. The organo-bentonite was then dried in an oven at temperature $105^{\circ} \mathrm{C}$ for $4 \mathrm{~h}$, crushed and sieved through $-100 /+120$ mesh screen.

\subsection{Characterizations of materials}

Natural bentonite and organo-bentonite were subjected to powder X-Ray Diffraction (XRD) analysis to examine whether the CTAB molecules were intercalated on the adsorbent structure. The Xray diffraction patterns of sample were recorded in a Bruker DS Advance diffractometer using $\mathrm{Cu} K \alpha$ radiation at $40 \mathrm{kV}, 40 \mathrm{~mA}$ and a step size of $0.01^{\circ}$. The carbon and nitrogen content of the natural and organo-bentonite were analyzed using an elemental-analyzer (Perkin-Elmer).

The natural bentonite and organo-bentonite were also characterized using Fourier Transform Infrared (FTIR) spectrometer to
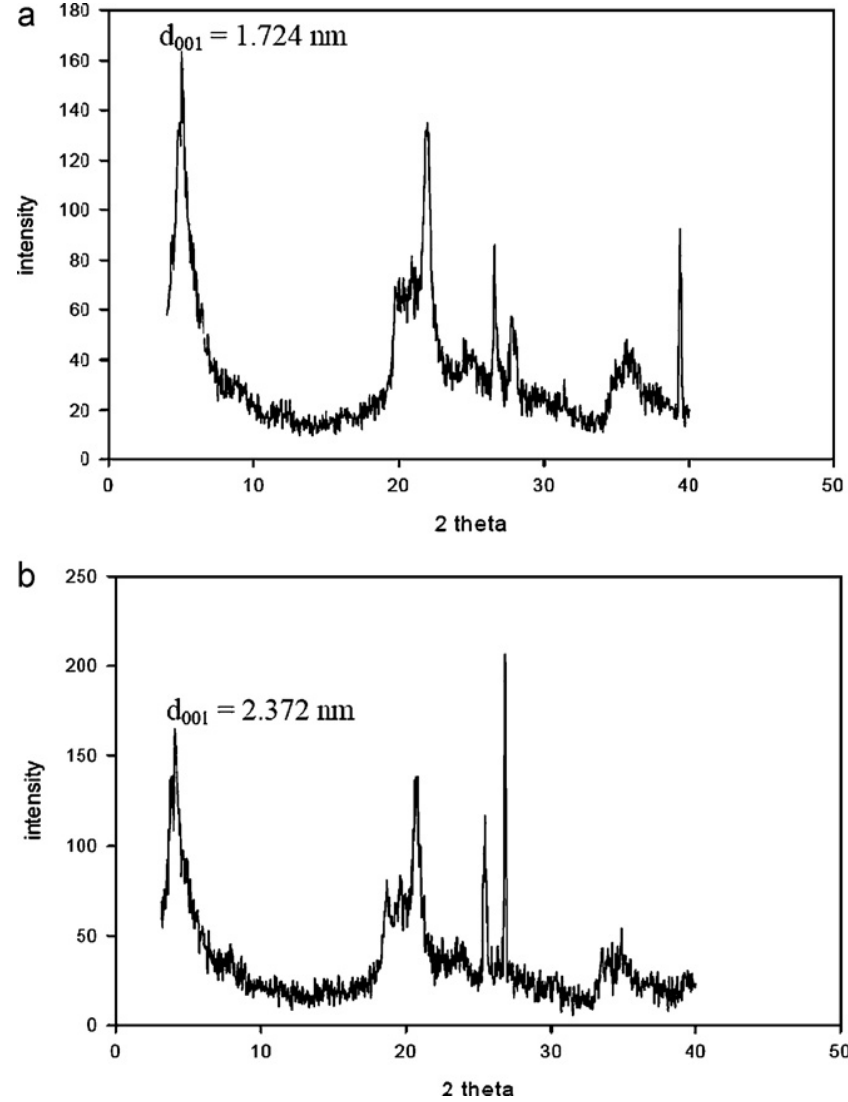

Fig. 1. XRD pattern of (a) natural bentonite and (b) organo-bentonite.

identify the surface functional groups. The analysis was performed based on $\mathrm{KBr}$ disk procedure and the sample spectra was recorded in a FTIR FTS-3500 GX (Bio-Rad) instrument at mid-IR wavenumber range of $500-4000 \mathrm{~cm}^{-1}$.

\subsection{Adsorption experiments of synthetic ampicillin solution}

The adsorption experiments were conducted by adding a known amount of natural or organo-bentonite into $250 \mathrm{~mL}$ iodine flasks containing $100 \mathrm{~mL}$ of ampicillin solution with an initial concentration of $300 \mathrm{mg} / \mathrm{L}(\mathrm{pH}=7.8)$. The solutions were then shaken in a thermostat shaker (Memmert) at $100 \mathrm{rpm}$ for $35 \mathrm{~min}$ at various temperatures $\left(30^{\circ} \mathrm{C}, 40^{\circ} \mathrm{C}\right.$ and $\left.50^{\circ} \mathrm{C}\right)$. Afterward, the flasks were removed from the bath and the mixtures were centrifuged (Hettich Zentrifugen EBA-20) at $2500 \mathrm{rpm}$ for $15 \mathrm{~min}$ to remove solid particle. The initial and equilibrium concentration of ampicillin in solution was determined spectrophotometrically in a GENESYS $10 \mathrm{~V}$ using Folin-Ciocalteu reagent [14]. All of adsorption experiments in this study were performed in triplicate and the results were given as average. The possible leaching of CTA cation during adsorption process was also checked by conductivity measurement using a WTW LF-535 conductometer. The experiment was carried out by adding organo-bentonite into distilled water and stirred for $30 \mathrm{~min}$. The solid suspension was then centrifuged and the conductivity of water was measured. The results showed that the conductivity of water did not change, indicated that CTA cation in the bentonite interlayer was not leached during the contact with water.

The amount of ampicillin adsorbed per was calculated by following mass-balance equation:

$q_{e}=\frac{C_{0}-C_{e}}{m} \times V$ 
Table 1

Elemental analysis of natural and organo-bentonite.

\begin{tabular}{lllll}
\hline Sample & $d_{001}(\mathrm{~nm})$ & $\mathrm{C}(\% \mathrm{wt})$ & $\mathrm{N}(\% \mathrm{wt})$ & $\mathrm{C} / \mathrm{N}$ molar ratio \\
\hline Natural bentonite & 1.72 & - & - & - \\
Organo-bentonite & 2.37 & 5.97 & 0.41 & 17 \\
\hline
\end{tabular}

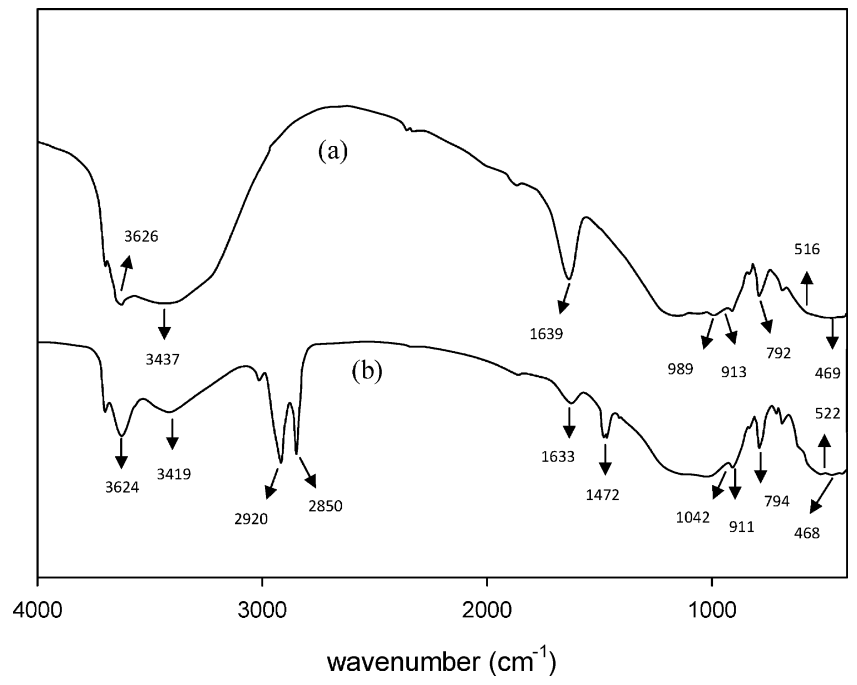

Fig. 2. Result of FTIR for (a) natural bentonite; (b) organobentonite.

where $C_{0}$ and $C_{e}$ are the initial and the equilibrium ampicillin concentrations in liquid phase $(\mathrm{mg} / \mathrm{L})$ respectively, $V$ is the volume of solution and $m$ is the mass of adsorbent.

\section{Results and discussion}

\subsection{Characterizations of materials}

The X-ray diffraction analysis was performed to characterize the layer structure of natural and organo-bentonite. The XRD patterns of sample were shown in Fig. 1. The increase of basal spacing from $1.72 \mathrm{~nm}$ to $2.37 \mathrm{~nm}$ was caused due to the intercalation of CTAB molecule onto the interlayer space of bentonite which expanded its interlamellar spacing and later will promote ampicillin removal. The elemental analysis of carbon and nitrogen in the organobentonite were also conducted to probe the presence of CTAB in the bentonite interlayer and the results were given in Table 1 .

The surface functional groups of materials were analyzed by FTIR spectroscopy. The spectra of both natural and organobentonite were given in Fig. 2 for direct comparison while the functional groups along with its corresponding wavenumber are summarized in Table 2 . In organo-bentonite, the symmetric and asymmetric vibration of $\mathrm{C}-\mathrm{H}$ stretch $\left(-\mathrm{CH}_{2}\right)$ was appeared at $2850 \mathrm{~cm}^{-1}$ and $2920 \mathrm{~cm}^{-1}$, respectively. The C-H stretch of CTA structure in-plane binding was noticed at $1472 \mathrm{~cm}^{-1}$. The bands at $516 \mathrm{~cm}^{-1}$ and $522 \mathrm{~cm}^{-1}$ were assigned to the Al-O-Si (octahedral layer) bend for natural and organo-bentonite, respectively. The $\mathrm{Si}-\mathrm{O}-\mathrm{Si}$ bend was also observed at $468 \mathrm{~cm}^{-1}$ for natural bentonite and $469 \mathrm{~cm}^{-1}$ for organo-bentonite.

\subsection{Adsorption isotherms}

In the liquid phase adsorption, many factors affect the adsorption process such as temperature, affinity of adsorbate, adsorbent concentration, and $\mathrm{pH}$. The adsorption isotherm is crucial importance in designing the adsorption system. Several isotherm equations are available and the most widely used for correlation of experimental data are Langmuir, Freundlich, Sips and Toth [15-17]. These models with their temperature dependent form are used to correlate the equilibrium data in this study. The nonlinear and linear form of Langmuir isotherm is given in the following equation [18]:

$q_{e}=q_{\max } \frac{C_{e} K_{L}}{1+C_{e} K_{L}}$

$\frac{1}{q_{e}}=\frac{1}{q_{\max }}+\frac{1}{K_{L} q_{\max } C_{e}}$

where $q_{e}$ is the equilibrium amount of ampicillin adsorbed ( $\mathrm{mmol} / \mathrm{g}), q_{\mathrm{max}}$ is the maximum adsorption capacity of the adsorbent $\left(\mathrm{mmol} / \mathrm{g}\right.$ ) and $K_{L}$ is the adsorption affinity or the Langmuir equilibrium constant $(\mathrm{L} / \mathrm{mmol})$. It is important that the temperature dependent form of isotherm parameters should be presented in correlating equilibrium data at various temperatures. The temperature dependent form of Langmuir parameter are given below $[19,20]:$

$q_{\max }(T)=q_{0} \exp \left(\delta\left(T_{0}-T\right)\right)$
$K_{L}=K_{0} \exp \left(\frac{-Q_{a d s}}{R T}\right)$

Here $q_{0}$ is the adsorption capacity at reference temperature $T_{0}$ $(\mathrm{mmol} / \mathrm{g}), \delta$ is the constant parameter related to the expansion coefficient of solute, $K_{0}$ is the adsorption affinity at same reference temperature ( $\mathrm{L} / \mathrm{mmol}), Q_{\mathrm{ads}}$ is the heat of adsorption $(\mathrm{J} / \mathrm{mol})$ and $R$ is the universal gas constant $(8.314 \mathrm{~J} / \mathrm{mol} \mathrm{K})$.

The Freundlich isotherm is an empirical model describing the adsorption process in heterogeneous systems which has nonlinear and linear form as follows [18]:

$q_{e}=K_{F} C_{e}^{1 / n}$

$\log q_{e}=\log K_{F}+\frac{1}{n} \log C_{e}$

where $K_{F}$ is the characteristic constant of Freundlich model related to the adsorption capacity $\left[(\mathrm{mmol} / \mathrm{g})(\mathrm{L} / \mathrm{mmol})^{-n}\right]$ and $n$ is the parameter characterizing the heterogeneity of the system. The temperature dependent form of these parameters is expressed below [20]:

$\frac{1}{n}=\frac{R T}{A_{0}}$

$K_{F}=K_{F_{0}} \exp \left(-\frac{\alpha R T}{A_{0}}\right)$

where $K_{F_{0}}$ is the adsorption capacity at reference temperature $T_{0}$ $\left[(\mathrm{mmol} / \mathrm{g})(\mathrm{L} / \mathrm{mmol})^{-n}\right], A_{0}$ is the characteristic of adsorption potential $(\mathrm{J} / \mathrm{mol})$ and $\alpha$ is a constant parameter.

Table 2

Surface functional groups of natural and organo-bentonite.

\begin{tabular}{lll}
\hline Peak assignment & \multicolumn{2}{l}{ Wavenumber $(1 / \mathrm{cm})$} \\
\cline { 2 - 3 } & $\begin{array}{l}\text { Natural } \\
\text { bentonite }\end{array}$ & $\begin{array}{l}\text { Organo- } \\
\text { bentonite }\end{array}$ \\
\hline $\mathrm{Al}-\mathrm{OH}$ or $\mathrm{Si}-\mathrm{OH}$ stretch & 3626 & 3624 \\
$\mathrm{O}-\mathrm{H}$ stretch $\left(\mathrm{H}_{2} \mathrm{O}\right)$ & 3437 & 3419 \\
$\mathrm{C}-\mathrm{H}$ stretch $\left(-\mathrm{CH}_{2}\right.$ of CTA structure) & - & 2920 \\
& - & 2850 \\
$\mathrm{O}-\mathrm{H}$ bend $\left(\mathrm{H}_{2} \mathrm{O}\right)$ & 1639 & 1633 \\
$\mathrm{C}-\mathrm{H}$ stretch $($ in-plane binding) & - & 1472 \\
$\mathrm{Si}-\mathrm{O}$ stretch (in-plane for silicate layer $)$ & 989 & 1042 \\
$\mathrm{Al}-\mathrm{Al}-\mathrm{OH}$ bend & 913 & 911 \\
$\mathrm{Si}-\mathrm{O}$ bend (quartz) & 792 & 794 \\
$\mathrm{Al}-\mathrm{O}-\mathrm{Si}$ bend & 516 & 522 \\
$\mathrm{Si}-\mathrm{O}-\mathrm{Si}$ bend & 469 & 468 \\
\hline
\end{tabular}


The Sips equation, which also called as Langmuir-Freundlich equation is one of three parameter model describing the adsorption process in heterogeneous system. The nonlinear and linear form of Sips model is $[18,20]$ :

$q_{e}=q_{\max } \frac{\left(C_{e} K_{S}\right)^{1 / n}}{1+\left(C_{e} K_{S}\right)^{1 / n}}$

$\ln \left(\frac{K_{S}}{q_{e}}\right)=\ln a_{S}-\frac{1}{n} \ln C_{e}$

where $K_{S}$ is the Sips constant related to adsorption affinity $(\mathrm{L} / \mathrm{mmol})$ and $n$ characterizes the system heterogeneity. The temperature dependent form of $K_{S}$ and $n$ can be expressed as [20]:

$K_{S}=K_{S_{0}} \exp \left[\frac{Q_{a d s}}{R T_{0}}\left(\frac{T_{0}}{T}-1\right)\right]$

$n=\frac{1}{\left(1 / n_{0}\right)+\eta\left(1-T_{0} / T\right)}$

where $K_{S_{0}}$ is the affinity coefficient at reference temperature $T_{0}, n_{0}$ is the value of parameter $n$ at the same reference temperature and $\eta$ is a constant parameter.

The Toth model is generally described well in many sorption studies with sub-monolayer coverage and heterogeneity of the system, which satisfying both low and high-end boundary of concentration. The nonlinear and linear forms of Toth equation can be expressed as follow $[18,20]$ :

$q_{e}=q_{\max } \frac{K_{T} C_{e}}{\left(1+\left(K_{T} C_{e}\right)^{t}\right)^{1 / t}}$

$\ln \left(\frac{q_{e}}{K_{T}}\right)=\ln C_{e}-\frac{1}{t} \ln \left(a_{T}+C_{e}\right)$

where $K_{T}$ is the Toth constant representing the affinity coefficient $(\mathrm{L} / \mathrm{mmol})$ while $t$ characterizes the system heterogeneity, which is a dimensionless constant and the value usually less than unity [20]. The parameter $K_{T}$ and $t$ are specific for particular adsorbate-adsorbent system which has temperature dependent form as follow [20]:

$K_{T}=K_{T_{0}} \exp \left[\frac{Q_{a d s}}{R T_{0}}\left(\frac{T_{0}}{T}-1\right)\right]$

$t=t_{0}+\eta\left(1-\frac{T_{0}}{T}\right)$

where $K_{T_{0}}$ is the affinity coefficient at reference temperature $T_{0}$, $t_{0}$ is the parameter $t$ at the same reference temperature and $\eta$ is a constant parameter.

The isotherm parameters of Eqs. (2)-(17) were calculated by using nonlinear least square fit of the model to the ampicillin adsorption equilibrium data. The fitting of equilibrium data were conducted for all temperatures of ampicillin adsorption isotherms simultaneously by using $T_{0}=298.15 \mathrm{~K}$. As the objective function to be minimized, the sum of squares errors was employed as follow:

$\operatorname{SSE}=\left(\frac{\left(\sum q_{e_{(\exp )}}-q_{e_{(\text {cal })}}\right)^{2}}{N}\right)^{1 / 2}$

where $q_{e_{(\exp )}}$ is the experimental amount of ampicillin adsorbed, $q_{e_{(c a l)}}$ is the calculated amount of ampicillin adsorbed and $N$ is the number of experimental data.

The temperature dependent parameters of Langmuir, Freundlich, Sips and Toth models obtained from the fitting procedure described previously were summarized in Table 3 while the equilibrium data of ampicillin adsorption along with the models fit were shown in Figs. 3 and 4. In these figures, it can be seen that all models could represent the equilibrium data fairly well. However, in
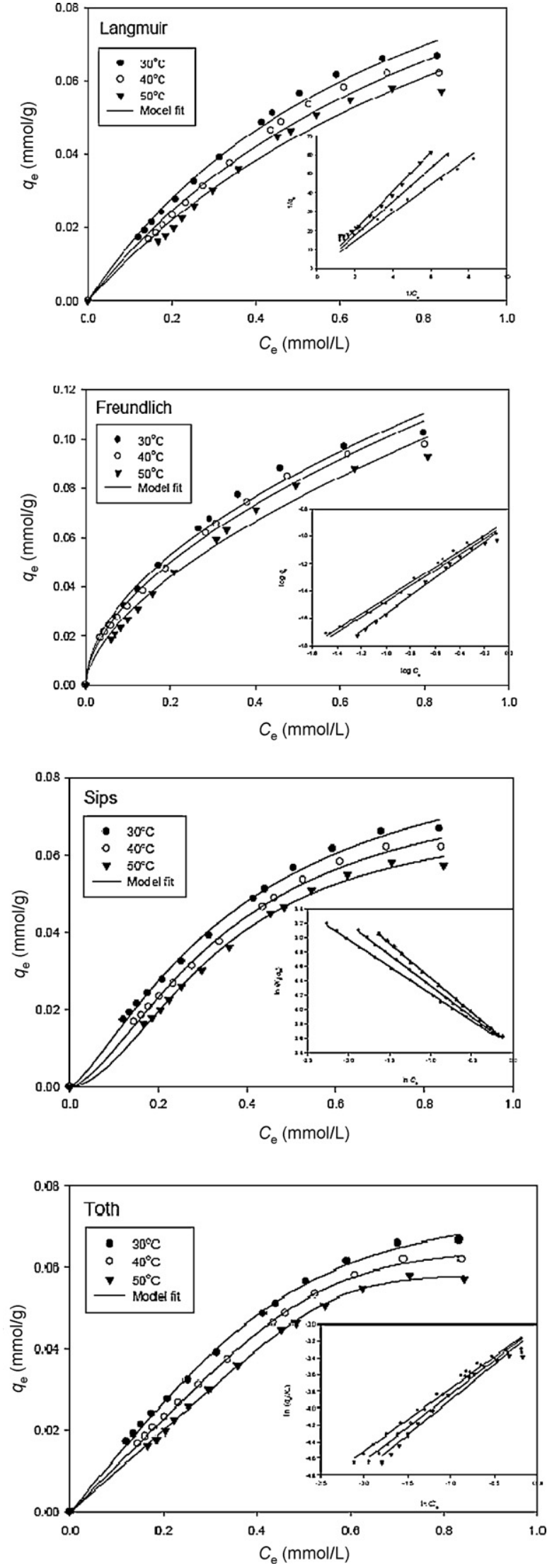

Fig. 3. Equilibrium data of ampicillin adsorption onto natural bentonite and the model fit (inset is the linear form of models) 

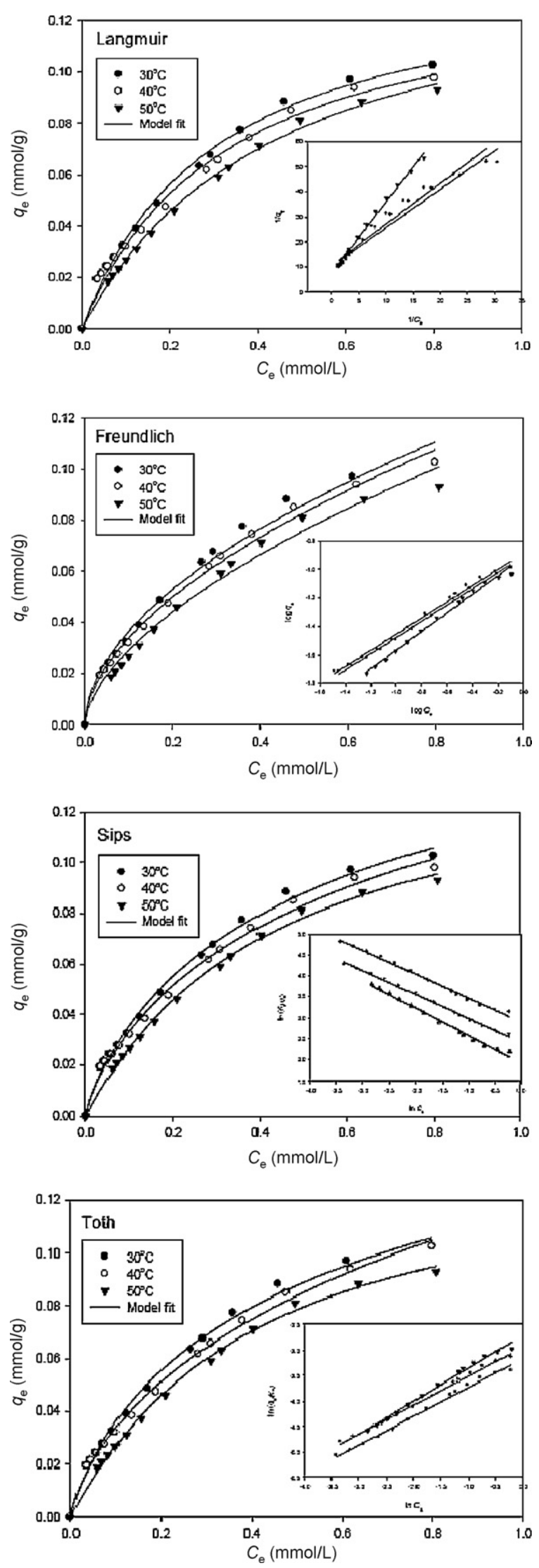

Fig. 4. Equilibrium data of ampicillin adsorption onto organo-bentonite and the model fit (inset is the linear form of models)
Table 3

The fitted parameters of temperature dependent form of several isotherm models.

\begin{tabular}{|c|c|c|c|}
\hline \multirow[t]{2}{*}{ Isotherm model } & \multirow[t]{2}{*}{ Parameter } & \multicolumn{2}{|l|}{ Adsorbent } \\
\hline & & $\begin{array}{l}\text { Natural } \\
\text { bentonite }\end{array}$ & $\begin{array}{l}\text { Organo- } \\
\text { bentonite }\end{array}$ \\
\hline \multirow[t]{5}{*}{ Langmuir } & $q_{0}(\mathrm{mmol} / \mathrm{g})$ & 0.1441 & 0.2477 \\
\hline & $\delta\left(\mathrm{K}^{-1}\right)$ & 0.006 & 0.0058 \\
\hline & $Q_{\text {ads }}(\mathrm{kJ} / \mathrm{mol})$ & 18.83 & 14.31 \\
\hline & $K_{0}(\mathrm{~L} / \mathrm{mmol})$ & 0.0007 & 0.0112 \\
\hline & SSE & 0.1 & 0.15 \\
\hline \multirow[t]{3}{*}{ Freundlich } & $K_{F_{0}}(\mathrm{mmol} / \mathrm{g})(\mathrm{L} / \mathrm{mmol})^{-n}$ & 0.5763 & 0.4439 \\
\hline & $-\alpha / A_{0}$ & 0.7677 & 0.5021 \\
\hline & SSE & 0.119 & 0.157 \\
\hline \multirow[t]{7}{*}{ Sips } & $q_{0}(\mathrm{mmol} / \mathrm{g})$ & 0.0657 & 0.1212 \\
\hline & $\delta\left(\mathrm{K}^{-1}\right)$ & 0.0032 & 0.0031 \\
\hline & $K_{S_{0}}(\mathrm{~L} / \mathrm{mmol})$ & 3.0898 & 3.1293 \\
\hline & $Q_{a d s}(\mathrm{~kJ} / \mathrm{mol})$ & 5.99 & 42.37 \\
\hline & $n_{0}$ & 0.829 & 1.554 \\
\hline & $\eta$ & 7.962 & 4.323 \\
\hline & SSE & 0.118 & 0.135 \\
\hline \multirow[t]{7}{*}{ Toth } & $q_{0}(\mathrm{mmol} / \mathrm{g})$ & 0.0545 & 0.0625 \\
\hline & $\delta\left(\mathrm{K}^{-1}\right)$ & 0.0087 & 0.0086 \\
\hline & $K_{T_{0}}(\mathrm{~L} / \mathrm{mmol})$ & 1.8532 & 3.5505 \\
\hline & $Q_{\text {ads }}(\mathrm{kJ} / \mathrm{mol})$ & 2.81 & 21.27 \\
\hline & $t_{0}$ & 1.443 & 0.085 \\
\hline & $\eta$ & 72.62 & 12.60 \\
\hline & SSE & 0.122 & 0.096 \\
\hline
\end{tabular}

order to explore the applicability of the models in correlating experimental data, the physical meaning of each parameter need to be analyzed. The ampicillin adsorption mechanism onto natural and organo-bentonite should also be discussed before examining the physical meaning of isotherm parameters in each model. As mentioned by Ho et al. [21] that linear analysis of Sips and Toth models involve trial and error procedure by varying isotherm parameter ( $K_{S}$ for Sips; $K_{T}$ and $a_{T}$ for Toth), often the parameter obtained is not the optimum one. Accordingly, the nonlinear least square fit method is still preferred to obtain the best fitted parameters for Sips and Toth models.

Ampicillin ( $\mathrm{p} K_{\mathrm{a}}=2.5$ for its free carboxylic acid groups and $\mathrm{p} K_{\mathrm{a}}=7.2$ for its free amino groups) is ionized in solution [4]. In basic solution, the silanol groups $(\mathrm{Si}-\mathrm{OH})$ of bentonite and ampicillin structure will deprotonate due to excessive amount of $\mathrm{OH}^{-}$ ions in the solution. At pH 7.8, the carboxylic acid and silanol groups was deprotonated as follow [2]:

$\equiv \mathrm{COOH}+\mathrm{OH}^{-} \rightarrow \mathrm{COO}^{-}+\mathrm{H}_{2} \mathrm{O}$

$\mathrm{Si}-\mathrm{OH}+\mathrm{OH}^{-} \rightarrow \mathrm{SiO}^{-}+\mathrm{H}_{2} \mathrm{O}$

The electrostatic repulsion between deprotonated silanol groups with negatively charged oxygen atoms of carboxylate anions was occurred as shown in Fig. 5, which retarded the adsorption process. In this case, the adsorption of ampicillin onto natural and organo-bentonite took place as a result of physical interaction such as Van der Waals force between the surface group of adsorbent and the adsorbate molecule. On modified bentonite (organo-bentonite), the presence of cethyltrimethylammonium cation (CTA) in bentonite interlayer played a positive role in the adsorption of ampicillin. With the presence of negatively charged carboxylic oxygen atom in ampicillin, an electrostatic interaction was occurred between positively charged organo-bentonite surface and negatively charged ampicillin (Fig. 6), resulting in the increase of the adsorption capacity for ampicillin removal.

The parameter $K_{F_{0}}$ in Freundlich and $q_{0}$ in Langmuir, Sips, and Toth model represent the adsorption capacity of the adsorbent. Based on the experimental data, it was obvious that modification of natural bentonite with CTAB surfactant enhanced its adsorption capacity. The parameter $q_{0}$ in Langmuir, Sips and Toth model was in 


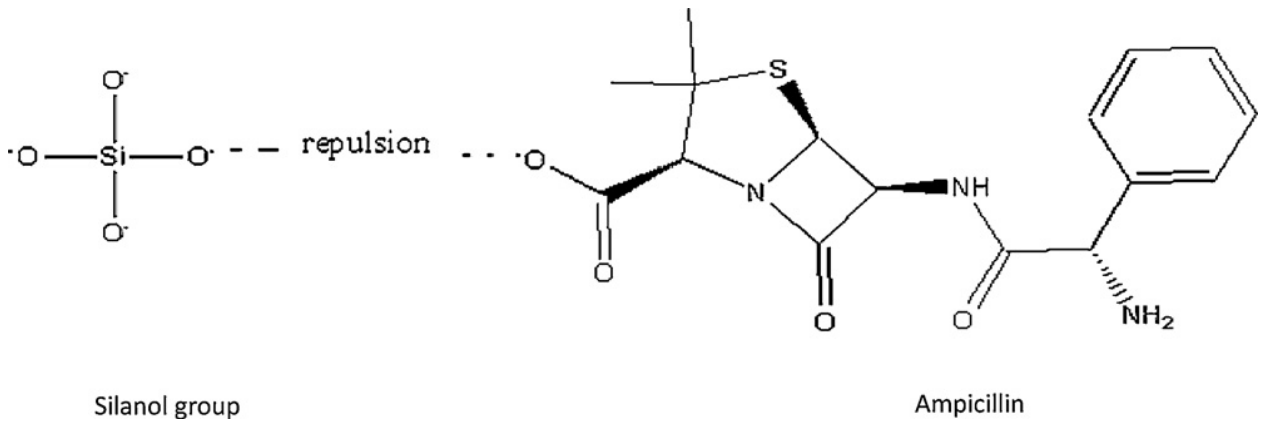

Fig. 5. Repulsion mechanism between deprotonated silanol group and negatively charged oxygen atom of carboxylic group.

agreement with the experimental data, however Freundlich model fails to give the correct value of $K_{F_{0}}$. The significant difference of $q_{0}$ value in Langmuir and Sips models for both natural and organobentonite may be due to the different theoretical justification of the models. In Langmuir model, the surface of the adsorbent is assumed to be homogeneous (heat of adsorption is constant over the sites) and ideal $(n=1)$ while in Sips and Toth models, the effect of heterogeneity of the adsorbent is included. Since the Freundlich model fails to give reasonable value for the adsorption capacity parameter, it will not be included in the further discussion.

The expansion coefficient of solute $(\delta)$ should be independent of the type of adsorbent and specific for a given component.
Table 4

Characteristics of synthetic and real wastewater.

\begin{tabular}{lcc}
\hline Parameter & $\begin{array}{l}\text { Synthetic } \\
\text { wastewater }\end{array}$ & $\begin{array}{l}\text { Real } \\
\text { wastewater }\end{array}$ \\
\hline $\mathrm{DO}(\mathrm{mg} / \mathrm{L})$ & 5.4 & 3.9 \\
$\mathrm{BOD}(\mathrm{mg} / \mathrm{L})$ & 19 & 304 \\
$\mathrm{COD}(\mathrm{mg} / \mathrm{L})$ & 296 & 2217 \\
$\mathrm{TSS}(\mathrm{mg} / \mathrm{L})$ & - & 14.8 \\
$\mathrm{pH}$ & 7.8 & 5.6 \\
$T\left({ }^{\circ} \mathrm{C}\right)$ & 30 & 30 \\
\hline
\end{tabular}<smiles>CC(C)(C)CCCCCCCCCCCCCCCCOS(=O)(=O)O</smiles>

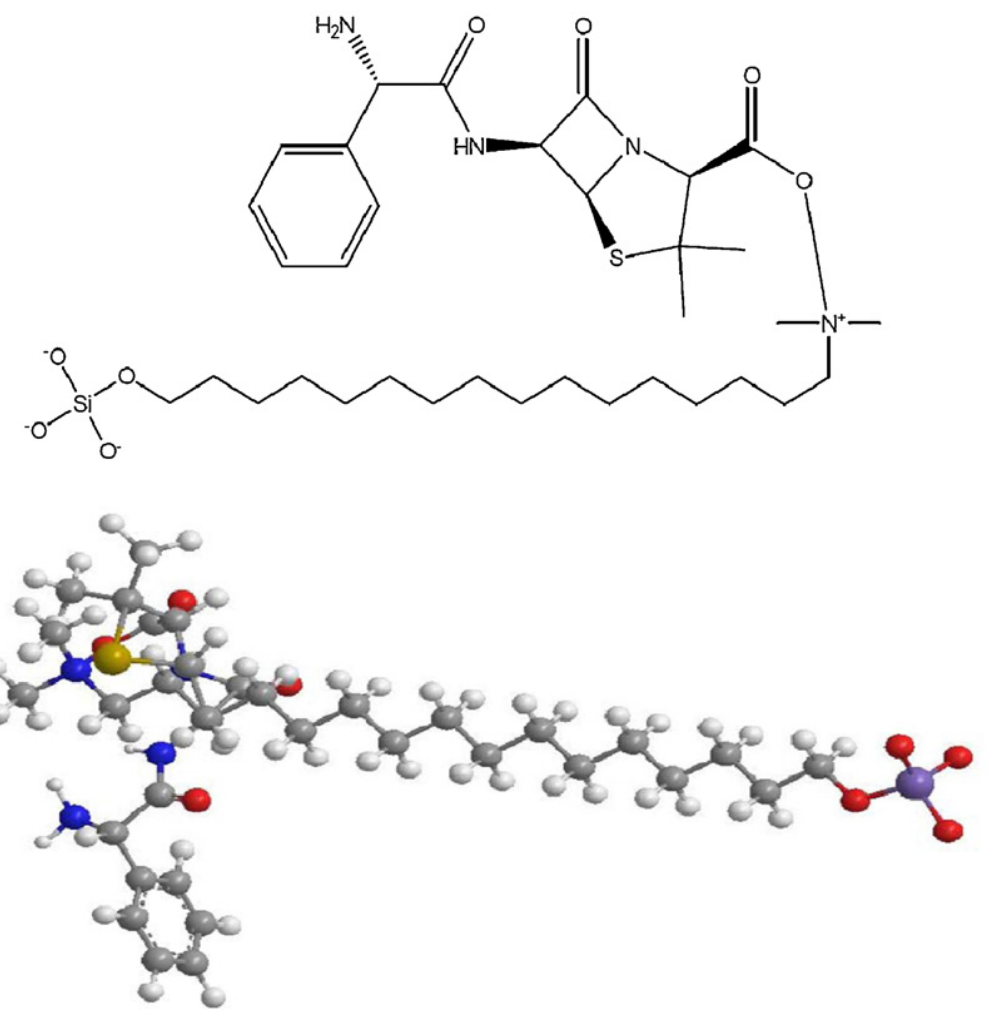

Fig. 6. Adsorption mechanism of ampicillin onto organo-bentonite. 
Table 5

Comparison of the adsorption performance of natural and organo-bentonite for ampicillin removal from synthetic and real wastewater.

\begin{tabular}{|c|c|c|c|c|}
\hline \multirow{2}{*}{$\begin{array}{l}\text { Parameter } \\
\text { Adsorbent }\end{array}$} & \multicolumn{2}{|c|}{ Synthetic wastewater } & \multicolumn{2}{|c|}{ Real wastewater } \\
\hline & $\begin{array}{l}\text { Natural } \\
\text { bentonite }\end{array}$ & $\begin{array}{l}\text { Organo- } \\
\text { bentonite }\end{array}$ & $\begin{array}{l}\text { Natural } \\
\text { bentonite }\end{array}$ & $\begin{array}{l}\text { Organo- } \\
\text { bentonite }\end{array}$ \\
\hline Adsorbent dose ( $\mathrm{g} / 100 \mathrm{~mL}$ solution) & 4.5 & 4.5 & 4.5 & 4.5 \\
\hline Initial concentration $(\mathrm{mg} / \mathrm{L})$ & 126.4 & 126.4 & 126.4 & 126.4 \\
\hline Final concentration (mg/L) & 12.7 & - & 51.4 & 11.9 \\
\hline \% removal & 89.9 & 100 & 59.3 & 90.6 \\
\hline
\end{tabular}

The value of $\delta$ parameter obtained from the fitting of Langmuir, Sips and Toth model is in agreement and independent of the type of adsorbate. Additionally, the value of $\delta$ in the magnitude of $10^{-3} \mathrm{~K}^{-1}$ is consistent with the value for many substances [19]. Based on the verification of $\delta$ parameter, the Langmuir, Sips and Toth model are still appropriate in correlating the experimental data.

How strong an adsorbate molecule attracts into the adsorbent surface is measured by the affinity parameter. In Langmuir model, the affinity parameter at $T_{0}$ is expressed as $K_{0}$ while for the Sips and Toth model are $K_{S_{0}}$ and $K_{T_{0}}$, respectively. When the affinity parameter is high, the solid surface is covered with more solutes as a result of stronger affinity towards the surface. Since the adsorption mechanism of ampicillin onto organo-bentonite also involved electrostatic attraction, thus the solute has stronger affinity towards the solid surface. The parameter $K_{S_{0}}$ in Sips model for both natural and organo-bentonite are similar hence the fitting values of this parameter are not consistent, so this model will not be included in the subsequent discussion. The fitting of affinity parameter of the Langmuir and Toth model are still consistent with experimental data.

One of the basic quantities in adsorption studies is the heat of adsorption. In case of physical adsorption, the released energy is partly adsorbed by the adsorbent and partly dissipated to the surrounding. The portion adsorbed by the solid increase the particle temperature and cause slows down the adsorption kinetics because the mass uptake is controlled by the rate of cooling of the particle in the later course of adsorption [20]. In chemisorption, a vice versa of phenomena takes place, in which higher temperature is favored for the adsorption process. Physisorption has an adsorption energy less than $40 \mathrm{~kJ} / \mathrm{mol}$ while higher energy (40-800 kJ/mol) reveals to chemisorption [22]. The parameter $Q_{\mathrm{ads}}$ in Langmuir and Toth model denotes the exothermic nature of ampicillin adsorption. In physical adsorption, the increase of temperature weakens the adsorbate-adsorbent interaction hence the amount of ampicillin adsorbed decreased. As mentioned above, other mechanism (electrostatic interaction) also took place during the adsorption of ampicillin onto organo-bentonite thus higher value of $Q_{\mathrm{ads}}$ is expected. The value of $Q_{\mathrm{ads}}$ parameter in Toth model is in agreement, in which the heat of adsorption of ampicillin onto organo-bentonite was higher than natural bentonite. Inconsistency of this fitting parameter was observed in Langmuir model.

The $t_{0}$ parameter characterizes the system heterogeneity. The parameter $t_{0}$ in Toth model is usually less than unity. The presence of CTA cation in the bentonite interlayer cause the adsorbent more heterogeneous and increase its adsorption capacity. The Toth model can represent this phenomenon and $t_{0}$ deviate further away from unity in the sorption system using organobentonite. Based on the evaluation of the physical meaning of fitted isotherm parameters of each model, it was clear that Toth model can represent the adsorption experimental data better than other models.

\subsection{Adsorption of ampicillin from real pharmaceutical wastewater}

In order to assess the feasibility of organo-bentonite to be used for wastewater treatment in industrial practice, the adsorption experiments of ampicillin from a pharmaceutical company wastewater (Coronet Crown Pty Ltd.) was also conducted. The synthetic wastewater contains only ampicillin while real wastewater may contain various substances. The DO concentration of both samples was measured by an OXI 96-B dissolved oxygen meter while $\mathrm{TSS}, \mathrm{BOD}_{5}$ and $\mathrm{COD}$ concentration were analyzed according to Standard Methods procedure [23]. The characteristics of the synthetic and real wastewater were given in Table 4.

The adsorption performance of natural and organo-bentonite for ampicillin removal from synthetic and real wastewater was reported in Table 5. In real wastewater, both adsorbents could not remove the ampicillin completely due to the sorption competition with other substances that also presented in the wastewater. In addition, lower removal efficiency of ampicillin onto natural bentonite in real wastewater may be due to the repulsion forces which occurred between deprotonated silanol groups $\left(\mathrm{Si}^{-} \mathrm{O}^{-}\right)$of bentonite and carboxylate anions $\left(\mathrm{COO}^{-}\right)$of ampicillin. The adsorption of ampicillin onto natural bentonite can still take place as a result of Van der Waals interaction and electrostatic interaction between protonated amine $\left(\mathrm{NH}_{3}{ }^{+}\right)$of ampicillin with deprotonated silanol $\left(\mathrm{Si}-\mathrm{O}^{-}\right)$of bentonite in less extent.

\subsection{Reusability of the adsorbent}

The reusability of adsorbent is a crucial importance in industrial practice to make the wastewater treatment become economic. The regeneration of organo-bentonite was performed by chemical treatment using diluted hydrochloric acid as an elution solution. The reusability of organo-bentonite was examined by carrying out of adsorption-desorption experiments in three cycles. In the third cycle, the removal efficiency of ampicillin from real wastewater using organo-bentonite still 84\%. Here, the application of organobentonite for the removal of ampicillin in industrial application still feasible.

\section{Conclusion}

The adsorption of ampicillin from aqueous solution onto natural and organo-bentonite was studied. The adsorption study was performed in batch system at various temperatures $\left(30^{\circ} \mathrm{C}, 40^{\circ} \mathrm{C}\right.$ and $50^{\circ} \mathrm{C}$ ). Modification of bentonite was conducted using CTAB surfactant by microwave heating at $600 \mathrm{~W}$ for $5 \mathrm{~min}$. The physical and chemical characterizations of materials were performed by FTIR, elemental-analyzer and XRD analysis. The widely used isotherm models (Langmuir, Freundlich, Sips, and Toth) with their temperature dependence form were employed to correlate the equilibrium data. It was found that Toth model could represent the equilibrium data better than other models used in this study. The electrostatic 
interaction between positively charged organo-bentonite and negatively charged ampicillin increased the removal efficiency. The ampicillin removal from real pharmaceutical wastewater was also conducted to evaluate the feasibility of organo-bentonite to be used as alternative adsorbent in industrial practice for environmental remediation.

\section{References}

[1] J.L. Martinez, Environmental pollution by antibiotics and by antibiotic resistance determinants, Environ. Pollut. 157 (2009) 2893-2902.

[2] E.K. Putra, R. Pranowo, J. Sunarso, N. Indraswati, S. Ismadji, Performance of activated carbon and bentonite for adsorption of amoxicillin from wastewater: mechanisms, isotherms and kinetics, Water Res. 43 (2009) 2419-2430.

[3] R. Hirsch, T. Ternes, K. Haberer, K.L. Kratz, Occurrence of antibiotics in the aquatic environment, Sci. Total Environ. 225 (1999) 109-118.

[4] D.D. Glover, D. Lalka, G.R.G. Monif, Ampicillin vs Penicillin for in utero therapy, Infect. Dis. Obstet. Gynecol. 4 (1996) 43-46.

[5] Z. Aksu, O. Tunc, Application of biosorption for penicillin G removal: comparison with activated carbon, Process Biochem. 40 (2005) 831-847.

[6] S. Suarez, F. Omil, J.M. Lema, Fate and removal of pharmaceuticals and personal care products (PPCPs) in a conventional activated sludge treatment, WIT Trans. Ecol. Environ. 135 (2010) 255-265.

[7] C.J. Wang, Z. Li, W.T. Jiang, J.S. Jean, C.C. Liu, Cation exchange interaction between antibiotic ciprofloxacin and montmorillonite, J. Hazard. Mater. 183 (2010) 309-314.

[8] A.J. Watkinson, E.J. Murbyc, S.D. Costanzo, Removal of antibiotics in conventional and advanced wastewater treatment: implications for environmental discharge and wastewater recycling, Water Res. 41 (2010) 4164-4174.

[9] Z. Pei, X.Q. Shan, J. Kong, B. Wen, G. Owens, Coadsorption of ciprofloxacin and $\mathrm{Cu}(\mathrm{II})$ on montmorillonite and kaolinite as affected by solution $\mathrm{pH}$, Environ. Sci. Technol. 44 (2010) 915-920.

[10] R.S. Al-Khalisy, A.M.A. Al-Haidary, A.H. Al-Dujaili, Aqueous phase adsorption of cephalexin onto bentonite and activated carbon, Sep. Sci. Technol. 45 (2010) 1286-1294.
[11] AJ. Carrasquillo, G.L. Bruland, A.A Mackay, D. Vasudevan, Sorption of ciprofloxacin and oxytetracycline zwitterions to soils and soil minerals: influence of compound structure, Environ. Sci. Technol. 42 (2008) 7634-7642.

[12] L.L. Li, L.D. Huang, R.S. Chung, K.H. Fok, Y.S. Zhang, Sorption and dissipation of tetracyclines in soils and compost, Phedosphere 20 (2010) 807-816.

[13] V. Homem, A. Alves, L. Santos, Amoxicillin removal from aqueous matrices by sorption with almond shell ashes, Int. J. Environ. Anal. Chem. 90 (2010) 1063-1084.

[14] A.S. Ahmad, N. Rahman, F. Islam, Spectrophotometric determination of ampicillin, amoxycillin, and carbenicillin using Folin-Ciocalteu phenol reagent, J. Anal. Chem. 59 (2009) 119-123.

[15] N.M. Mahmoodi, B. Hayati, M. Arami, C. Lan, Adsorption of textile dyes on Pine Cone from colored wastewater: kinetic, equilibrium and thermodynamic studies, Desalination 268 (2011) 117-125.

[16] S. Ismadji, S.K. Bhatia, Adsorption of flavour esters on granular activated carbon, Can. J. Chem. Eng. 78 (2000) 892

[17] A. Kurniawan, H. Sutiono, Y.H. Ju, F.E. Soetaredjo, A. Ayucitra, A. Yudha, S. Ismadji, Utilization of rarasaponin natural surfactant for organo-bentonite preparation: application for methylene blue removal from aqueous effluent Micropor. Mesopor. Mater. 142 (2011) 184-193.

[18] K.Y. Foo, B.H. Hameed, Insights into the modeling of adsorption isotherm systems, Chem. Eng. J. 156 (2010) 2-10.

[19] S. Ismadji, S.K. Bhatia, A modified pore-filling isotherm for liquid phase adsorption in activated carbon, Langmuir 17 (2001) 1488-1498.

[20] D.D. Do, Adsorption Analysis: Equilibria and Kinetics, Imperial College Press, London, UK, 1998.

[21] Y.S. Ho, J.F. Porter, G. McKay, Equilibrium isotherm studies for the sorption of divalent metal ions onto peat: copper, nickel and lead single component systems, Water Air Soil Pollut. 141 (2002) 1-33.

[22] E. Eren, B. Afsin, Investigation of a basic dye adsorption from aqueous solution onto raw and pre-treated bentonite surfaces, Dyes Pigments 76 (2008) 220-225.

[23] Standard Methods for the Examination of Water and Wastewater, American Public Health Association (APHA), American Water Works Association (AWWA) and Water Environment Federation (WEF), 20th ed., Washington, DC, USA 1995. 